\title{
The evidence of associations between prion protein genotype and production, reproduction, and health traits in sheep
}

\author{
Torres SWEENEY ${ }^{1 *}$, John P. HANRAHAN ${ }^{2}$ \\ ${ }^{1}$ School of Agriculture, Food Science and Veterinary Medicine, Conway Institute of Biomolecular and \\ Biomedical Sciences, University College Dublin, Belfield, Dublin 4, Ireland \\ ${ }^{2}$ Teagasc, Animal Production Research Centre, Athenry, Co, Galway, Ireland
}

(Received 28 September 2007; accepted 15 January 2007)

\begin{abstract}
The EU Commission issued a regulation in 2003, which requires all member states to implement a breeding programme for resistance to transmissible spongiform encephalopathies in sheep by selecting for specific alleles of the prion protein $(\operatorname{Pr} P)$ gene. A key concern with regard to this regulation was that the intensive selection programmes, designed to increase resistance to scrapie, may have a negative impact on a range of other economically important production, reproduction, and disease traits in sheep. Such problems could arise for a number of reasons. Firstly, a number of breeds have a low frequency of the resistant $\operatorname{Pr} P$ allele. Secondly, there may be a negative association between the resistant allele and animal performance. Thirdly, selection for scrapie resistance may reduce the rate of improvement towards current breeding goals. The evidence concerning the relationship between $\operatorname{Pr} P$ genotype and reproduction, production, and disease traits is the subject of this review. We conclude that there is no evidence for a negative association between $\operatorname{PrP}$ genotype and reproduction traits (e.g. litter size), lamb performance traits (e.g. growth rate, conformation, carcass composition) or milk production. There is, however, a distinct paucity of information on the relationship between the $\operatorname{Pr} P$ gene and disease traits. In this context it is noted that there are a number of genes located on chromosome 13, in close proximity to the $\operatorname{Pr} P$ gene, that are involved in intracellular cell signalling, apoptosis, phagocytosis, and immune function. Thus further direct studies of key disease traits associated with sheep production systems are warranted.
\end{abstract}

$\operatorname{PrP}$ genotype / growth / carcass / prolificacy / disease

Table of contents

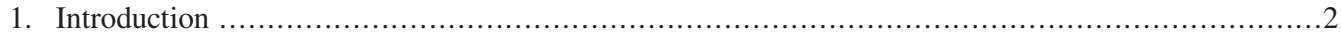

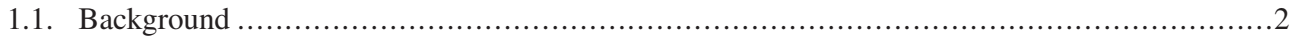

1.2. How could selection for alleles of the $\operatorname{Pr} P$ gene influence performance traits? ....................

2. Is there an association between the $\operatorname{Pr} P$ gene and performance traits? ................................

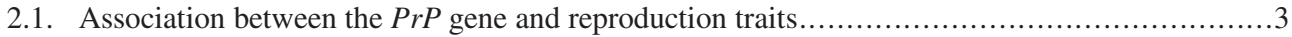

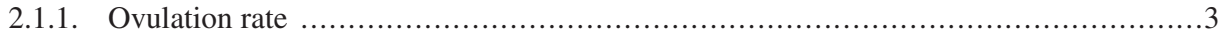

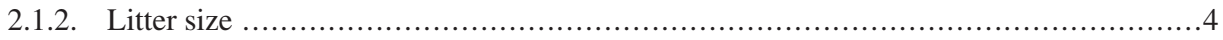

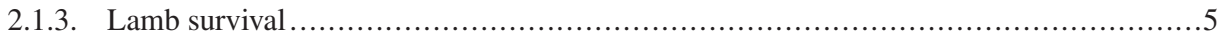

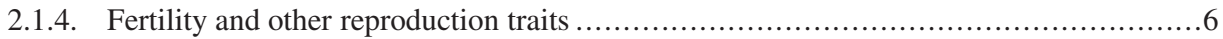

2.2. Association between the $\operatorname{Pr} P$ gene and lamb growth and carcass traits .........................6

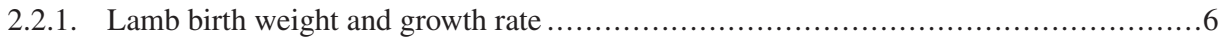

2.2.2. Carcass conformation and composition ............................................... 8

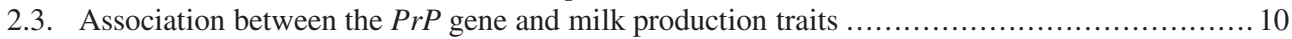

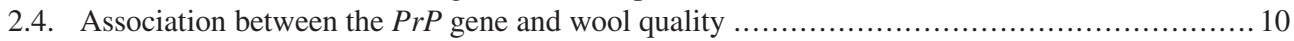

* Corresponding author: torres.sweeney@ucd.ie 
2.5. Association between the $\operatorname{Pr} P$ gene and disease traits .............................................. 10

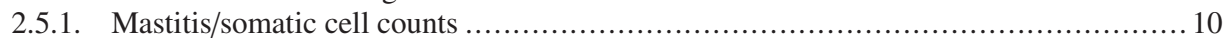

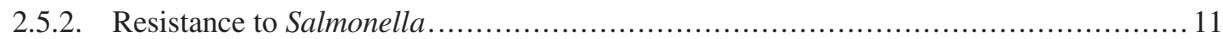

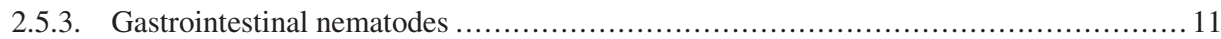

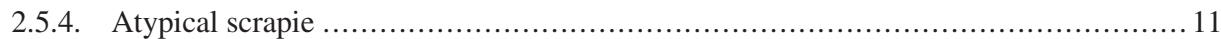



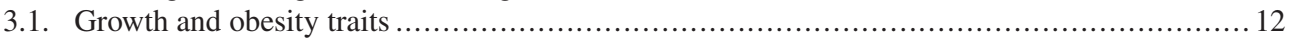

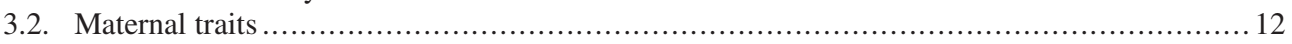

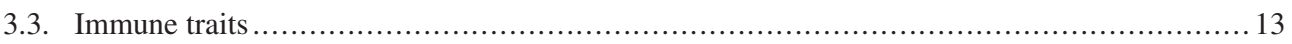

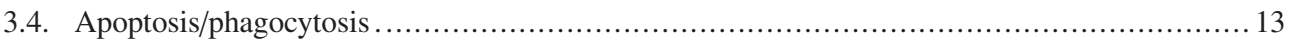

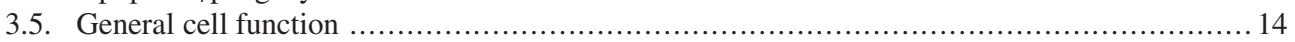

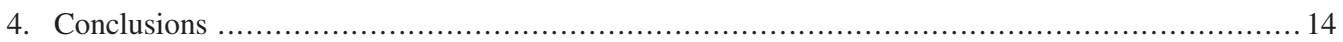

\section{INTRODUCTION}

\subsection{Background}

The concern that bovine spongiform encephalopathy (BSE) may have entered the sheep population $[34,47]$ and is not obviously distinguishable from classical scrapie [14] prompted the EU Commission Decision 2003/100/EC, which requires member states to implement a breeding programme for resistance to transmissible spongiform encephalopathies (TSE) in sheep. While the resistance status of a sheep flock to classical scrapie and BSE can be rapidly improved by selective breeding $[5,23]$, the relative economic value of such selection must be considered in the context of all of the other breeding objectives in local, national, and international breeding plans.

The ovine prion protein gene spans $31 \mathrm{~kb}$ and consists of two short non-coding exons and one exon that contain the open reading frame spanning 236 codons [50]. This gene was mapped to chromosome 13 [17]. Resistance to classical scrapie and BSE is associated with polymorphisms at codons A136V, $\mathrm{R} 154 \mathrm{H}$, and R171Q of the prion protein $(\mathrm{PrP})$ gene. The ARR allele has been associated with resistance to scrapie. However, the experimental infection of homozygous ARR sheep with BSE [42] and the recent detection of two cases of classical scrapie in ARR homozygous sheep [38] imply that resistance is not absolute in ARR homozygous individuals. The AHQ, ARH, ARQ, and VRQ alleles are generally associated with susceptibility. The degree of, and the ranking for, susceptibility appears to be breed dependent, with the VRQ allele (when present within a breed) generally considered the most susceptible $[7,8,31,44,61,64,77,79]$. There is also evidence to suggest that polymorphisms at other codons within the $\operatorname{PrP}$ gene may modify the degree of resistance associated with the ARQ allele [82].

Breeding programmes designed to select for animals with an ARR allele could encounter three main problems. Firstly, a number of breeds have a low frequency of the ARR allele $[1,29,63,81]$. Hence selection of a small number of breeding rams carrying the ARR allele would increase the rate of inbreeding and the likelihood of genetic drift [24]. This would result in reduced additive genetic variation in future generations. In these cases, initial selection goals may be focused on eliminating the most susceptible allele in the breed. Secondly, selection on the $\operatorname{PrP}$ genotype will reduce selection pressure on other traits and thus genetic gain for traits in current breeding goals maybe reduced. Thirdly, there may be a negative association between the ARR allele and animal performance traits.

\subsection{How could selection for alleles of the $\operatorname{Pr} P$ gene influence performance traits?}

While the biological function of the prion protein has not been definitively identified, the conservation of the structure of the prion protein throughout the class Mammalia suggests that this protein probably plays an important role in metabolism and/or homeostasis. Some suggested roles are reviewed [43] and include signal transduction, synaptic transmission, and 
protection against cell death. The prion protein is expressed in a wide variety of different organs, tissues and cells throughout the foetal and adult body and in cell lines $[4,37,57,60$, $65,66,78]$.

Selection for alleles of the $\operatorname{PrP}$ gene could affect traits other than susceptibility to scrapie due to either: (i) pleitropic effects of the $\operatorname{PrP}$ locus, or (ii) genetic linkage between the $\operatorname{Pr} P$ locus and loci affecting production traits. A pleiotropic role for the $\operatorname{PrP}$ gene has previously been suggested following the characterisation of a spatio-temporal expression of the gene in neuronal, non-neuronal cells, and in extra-embryonic tissue during mouse embryogenesis [57]. While the role of the $\operatorname{PrP}$ gene in susceptibility to the development of scrapie has been well characterised, there is no specific evidence, to date, that the gene directly affects other traits. Alternatively, in any particular population, the $\operatorname{Pr} P$ gene may be in linkage disequilibrium with genes that affect other traits. Thus selection for particular alleles of the $\operatorname{PrP}$ gene will inadvertently select a specific variant for the other trait.

Hence, a number of research groups have focused their attention on determining if there is an association between $\operatorname{Pr} P$ genotype and the main production and reproduction traits and, to a lesser extent, disease traits. These studies are presented in Section 2. While this approach has yielded very valuable information, an alternative strategy is to use bioinformatics to identify genes on chromosome 13 and to hypothesise which of these genes are most likely to be in linkage disequilibrium with the prion protein gene. Available evidence for this approach and traits that could be affected is presented in Section 3 .

\section{IS THERE AN ASSOCIATION BETWEEN THE $\operatorname{PrP}$ GENE AND PERFORMANCE TRAITS?}

The EU decision requiring member states to implement breeding programmes to increase resistance of sheep populations to TSE prompted extensive investigations on the possible consequences for the profitability of sheep production enterprises. These studies have largely involved traits that are routinely measured in national breeding programmes. The evidence from the large number of studies involving reproduction traits and lamb performance traits is presented by breed in this review, as this is the most rational unit for evaluating possible linkage effects. We have highlighted cases where a significant effect was detected even though this may have been one of many comparisons within the analyses of any particular study.

\subsection{Association between the $\operatorname{Pr} P$ gene and reproduction traits}

The productivity of breeds that represent or contribute to commercial ewe flocks is one of the fundamental pillars of an efficient and competitive sheep industry, and the key traits in this context are litter size, maternal ability, fertility, conception rate, embryo and postnatal survival, and seasonality (in production systems that exploit less than annual lambing intervals). Ovulation rate is also a key variable as it is the main determinant of litter size. Some of these traits have received considerable attention in the literature while information on others (embryo and postnatal survival, male fertility, and other measurements of male reproductive performance) is scant or non-existent.

\subsubsection{Ovulation rate}

Ovulation rate is a fundamental component of reproductive efficiency and is the principal source of genetic variation in litter size. There is considerable variability among and within breeds of sheep for this trait $[11,71]$, and a number of genes with large effects on ovulation rate have been identified and/or implicated in the control of ovulation rate [19-22,36,40]. None of the known genes are located on chromosome 13 and hence are not of concern here.

There is currently no evidence in the literature to suggest that there is any relationship between $\operatorname{Pr} P$ genotype and ovulation rate in sheep. In a study involving approximately 600 genotyped ewes of the INRA 401 breed [84], there was no evidence for any difference in comparisons among the genotypes ARR/ARR, $\mathrm{ARR} / *$ and $* / *$, where $*$ denotes any allele except ARR $(P>0.5$, except for the contrast 
Table I. Association between $\operatorname{Pr} P$ genotype and litter size.

\begin{tabular}{lccc}
\hline Breed & Authors & & Evidence for an association \\
\hline Belclare & Sweeney et al., 2007 & {$[76]$} & N.S. \\
Cheviot & Chase-Topping et al., 2005 & {$[18]$} & N.S. \\
Coburg Fox & Lipsky et al., 2006 & {$[53]$} & N.S. \\
Columbia & Alexander et al., 2005 & {$[2]$} & N.S. \\
Commercial western white-faced & Alexander et al., 2005 & {$[2]$} & $P<0.01$ \\
East Friesian Milk Sheep & De Vries et al., 2005 & {$[27]$} & N.S. \\
& Lipsky et al., 2006 & {$[53]$} & N.S. \\
Gary Horned Heath & Lipsky et al., 2006 & {$[53]$} & N.S. \\
German Black-Headed Mutton & De Vries et al., 2004 & {$[25]$} & N.S. \\
& Lipsky et al., 2006 & {$[53]$} & N.S. \\
Hampshir & Alexander et al., 2005 & {$[2]$} & N.S. \\
INRA 401 sheep & Chase-Topping et al., 2005 & {$[18]$} & N.S. \\
& Vitezica et al., 2006 & {$[84]$} & N.S. \\
Lacaune & Moussaoui et al. & & N.S. \\
Manchega & Moussaoui et al. & & N.S. \\
Merinoland & Lipsky et al., 2006 & {$[53]$} & N.S. \\
Rambouillet & Alexander et al., 2005 & {$[2]$} & N.S. \\
Rasa Arogonesa & Ponz et al., 2006 & {$[69]$} & N.S. \\
Rhoen & Lipsky et al., 2006 & {$[53]$} & N.S. \\
Ripollesa & Casellas et al., 2007 & {$[16]$} & $P<0.05$ \\
Shropshire & Lipsky et al., 2006 & {$[53]$} & N.S. \\
Suffolk & De Vries et al., 2004 & {$[25]$} & N.S. \\
& Alexander et al., 2005 & {$[2]$} & $P<0.01$ \\
Lipsky et al., 2006 & {$[53]$} & N.S. \\
Texel & Chase-Topping et al., 2005 & {$[18]$} & N.S. \\
& De Vries et al., 2004 & {$[25]$} & N.S. \\
Texel-Booroola & Brandsma et al., 2004 & {$[12]$} & $P<0.05$ \\
\hline & Lipsky et al., 2006 & {$[53]$} & N.S. \\
& Brandsma et al., 2005 & {$[13]$} & N.S. \\
\hline & & &
\end{tabular}

between $\mathrm{ARR} / *$ and $* / *$ where $P=0.15$ ). Likewise, in a study involving approximately 400 genotyped Belclare ewes [76], there was no effect of the $\operatorname{Pr} P$ genotype on ovulation rate $(P>0.8)$. The two breeds involved are recently developed prolific composites and thus should be informative material if any gene with a large effect on ovulation rate was located on chromosome 13. However, information on other more traditional breeds is warranted.

\footnotetext{
${ }^{1}$ Moussaoui Y., Caja G., Casellas J., Such X., Francino O., Asociaiones entre genotipo $\operatorname{Pr} P$ y caracteres productivos en ovino lechero de raza Manchega y Lacune: Primeros resultados en prolificidad y peso nacimiento, Congressos/AIDA, 2005, p. 3 .
}

\subsubsection{Litter size}

The available evidence on the association between $\operatorname{Pr} P$ genotype and litter size is presented in Table I. The table contains results from 29 evaluations of which four indicate some evidence for a significant association, namely in Suffolk, Texel, and Ripollesa breeds, and in a flock of ewes described as commercial western white-faced.

The evidence for an effect in Suffolk and Texel is inconsistent across studies. In the case of the effect in the Suffolk [2] the difference reflected a higher litter size in ewes that did not have $\mathrm{R}$ at codon 171 compared with ewes that were heterozygous $\mathrm{R}$ at this codon (because of the paucity of records for animals homozygous $\mathrm{R}$ at codon 171 , these animals were excluded from the analysis). The total 
number of ewes involved in this analysis was small $(n=63)$. Also, the model used was not specified and it is thus not possible to determine if the repeated records per ewe and the possible confounding effects of year and ewe age were accommodated in the analysis. None of the other three studies involving Suffolk sheep showed any evidence of an association; in particular, the study of De Vries et al. [25] involved a large number of ewes in each genotype class and the differences between ARR carriers and ARQ/ARQ animals did not even approach significance. Thus it seems reasonable to conclude that there is no compelling evidence for any association in the Suffolk breed.

In the Texel breed, the study that yielded a significant effect [12] was based on the expected breeding value for litter size of a large number of Dutch Texel rams and showed that carriers of the ARR allele had a significantly greater estimated breeding value (EBV) for litter size than $\mathrm{ARQ}^{*} / \mathrm{ARQ}^{*}$ (where ARQ* signifies ARQ or ARH). The effect from one copy of the ARR allele was equivalent to an increase of 0.03 in litter size while the effect for ARR/ARR animals was equivalent to an increase of 0.06 in litter size. There was also a significant increase in litter size in carriers of the VRQ allele $(+0.1)$ compared with ARQ*/ARQ*. The estimates of association in the study on the Texel-Booroola ewe population [13], which was produced by introgression of the Booroola gene into a Dutch Texel flock (the animals studied were at least $75 \%$ Texel ancestry), did not support the estimates based on EBV values for purebred Dutch Texel rams. Thus, ARR/ARR ewes had a numerically lower litter size than ARQ*/ARQ* ewes although the difference between ARR/ARQ* and $\mathrm{ARQ}^{*} / \mathrm{ARQ}^{*}$ was in the same direction as in the study of Brandsma et al. [12]. Two studies in German Texels yielded no evidence of a significant association between $\operatorname{PrP}$ genotype and litter size $[25,53]$. These conflicting results suggest that the evidence for any association of $\operatorname{Pr} P$ allele and ovulation rate in the Texel breed is weak.

The significant effect noted for commercial western white-faced ewes [2] reflected a very low litter size in ewes homozygous for $\mathrm{R}_{171}$ codon and the number of ewes involved was reasonably large. The effect may be due to the mixed-breed nature of the population involved, which is presumed to be akin to Whiteface Western sheep, described in Porter [70] as grade Rambouillet or mixtures of Rambouillet with Merino, Columbia, or Corriedale. Thus, breed differences in allele frequency at the $\operatorname{PrP}$ locus and breed differences in prolificacy could be confounded. Caselas et al. [16] evaluated the effects of allele substitution for three alleles (ARR, ARH, and ARQ) in the Ripolessa breed. The substitution of the ARH allele increased litter size relative to ARQ and ARR, however only the contrast with ARQ was significant. It must be noted that the ARH allele had the lowest frequency $(0.13)$ in the population studied and the total number of animals in the study was small $(n=89)$.

As the proportion of studies which reported evidence of an association between litter size and $\operatorname{PrP}$ genotype is small and since the associations detected were not consistent and generally weak, except for the commercial western white-face (which may reflect confounding effects of breed differences in $\operatorname{PrP}$ gene frequency and prolificacy), it is concluded that there is no convincing evidence for an association between the $\operatorname{Pr} P$ and litter size.

\subsubsection{Lamb survival}

There is little direct information on this topic in the literature in the context of performance in a "scrapie free" production environment. Lamb mortality/survival was reported in nine sheep breeds in Germany [53]. The traits examined were number of lambs dead per ewe (i.e. either born dead or died within 56 days of age) and rearing rate (percentage of lambs weaned of those born). Significant associations were detected between $\operatorname{Pr} P$ genotype and number of dead lambs in the Shropshire breed $(P<0.05$; ARR carriers had more dead lambs). The rearing rate in Shropshire ewes without an ARR allele was also significantly higher than for ARR heterozygotes $(96.7 \%$ versus $86.5 \% ; P<0.05)$. The number of genotyped animals was small (44) and thus these findings should be treated with some caution. 
There was no difference between ARR/ARR and ARQ/ARQ rams for the number of lambs born or reared per ewe lambing among ewes joined with Suffolk, Texel, or Charollais rams [41], which can be interpreted to indicate that there is no direct association between embryo or postnatal survival and the allele inherited from the sire. Finally, embryos homozygous for the VRQ allele did not differ, in terms of prenatal or early postnatal survival, from embryos that were heterozygous for the VRQ allele ${ }^{2}$. However, recent results from a large-scale study of Scottish Blackface lambs showed that ARQ heterozygotes had a significantly higher survival rate than animals without the ARQ allele, while ARR homozygote animals had a significantly lower survival rate than either ARR heterozygotes or non-carriers ${ }^{3}$.

\subsubsection{Fertility and other reproduction traits}

Information on other traits related to reproductive performance is limited. There was no evidence for an association between $\operatorname{Pr} P$ genotype and fertility in the INRA 401 breed [84]. Similarly, there was no association between $\operatorname{Pr} P$ genotype and fertility (conception rate was the term used, but the trait measured was fertility) in the Ripollesa breed [16].

There was no evidence for any association between $\operatorname{Pr} P$ genotype and age at first lambing in Suffolk, Texel, or German Black-Headed Mutton breeds [25]. However, these authors found significant associations for the interval between second and third lambing, which was longer $(P<0.01)$ for carriers of the ARR allele in the Suffolk but shorter $(P<0.01)$ in ARR homozygotes than in ARR heterozygotes in the case of the German Blackhead-Mutton

\footnotetext{
${ }^{2}$ Thornton K., Hanrahan J.P., Aherne M., Negredo C., Sweeney T., Prenatal and early postnatal survival of VRQ homozygous sheep and the implications for susceptibility to scrapie in the sheep population. Conference on methods for control of scrapie 15 and 16 May 2003, Oslo, Norway, p. 70.

${ }^{3}$ Sawalha R., Brotherstone S., Conington J., Villaneuva B., Association of $\operatorname{PrP}$ gene with neonatal lamb survival, Proceedings of the third International Congress on Quantitative Genetics, 2007.
}

[25]. However there was no significant effect on the interval between first and second lambing in any of the breeds studied. Age at first lambing, and first and second lambing intervals were also examined in East Friesian sheep [27]. No evidence was found for an association with $\operatorname{PrP}$ genotype for any of these traits. The significant effects for the interval between second and third lambings in two populations suggest that more evidence should be sought on associations with seasonality. There is only one study in the literature exploring the relationship between $\operatorname{PrP}$ genotype and male fertility traits [10]. These authors found no evidence for any association of $\operatorname{Pr} P$ genotype and ejaculate volume, number of sperm per ejaculate, sperm concentration, or motility in the Lacaune breed.

\subsection{Association between the $\operatorname{Pr} P$ gene and lamb growth and carcass traits}

A difficulty with compiling a summary of the studies of the association between the prion protein gene and lamb growth and carcass traits is the multiplicity of traits considered and the variable definitions of these traits across studies. In order to render the summary concise and inclusive we have chosen to concentrate on birth weight, weight at weaning (which is usually between 90 days and 120 days in non-intensive production systems), and live weight at slaughter. In some cases only growth rate to weaning was available and this has been used instead of weaning weight. Since there is a close relationship between all measures of early growth, these variables should provide an adequate indication of the likelihood of an association between $\operatorname{Pr} P$ genotype and lamb growth performance.

\subsubsection{Lamb birth weight and growth rate}

There are a large number of studies on lamb growth traits and the main features of these are summarised in Table II. There were significant effects for birth weight in two breeds. Scottish Blackface lambs heterozygous for ARQ had a higher birth weight than ARQ/ARQ lambs 
Table II. Association between $\operatorname{Pr} P$ genotype and lamb growth traits.

\begin{tabular}{|c|c|c|c|c|c|}
\hline \multirow{2}{*}{ Breed } & \multicolumn{2}{|l|}{ Authors } & \multirow{2}{*}{$\begin{array}{c}\text { Birth } \\
\text { weight }\end{array}$} & \multirow{2}{*}{$\begin{array}{l}\text { Weaning } \\
\text { weight }^{\mathrm{a}}\end{array}$} & \multirow{2}{*}{$\begin{array}{c}\text { Slaughter } \\
\text { weight }\end{array}$} \\
\hline & & & & & \\
\hline Blanc du Massif Central & Vitezica et al., 2005 & {$[83]$} & - & N.S. & - \\
\hline Charollais & Moore et al. ${ }^{4}$ & [41] & - & N.S. & - \\
\hline & Hanrahan et al., 2008 & & N.S. & N.S. & \\
\hline Cheviot & Tongue et al., 2006 & {$[80]$} & N.S. & - & - \\
\hline Columbia & Alexander et al., 2005 & {$[2]$} & N.S. & N.S. & - \\
\hline Commercial western white-faced & Alexander et al., 2005 & {$[2]$} & N.S. & N.S. & - \\
\hline \multirow[t]{2}{*}{ Dorset } & Isler et al., 2006 & {$[46]$} & N.S. & N.S. & N.S. \\
\hline & Tongue et al., 2006 & {$[80]$} & $P<0.01$ & - & - \\
\hline German Black-Headed Mutton & De Vries et al., 2004 & {$[26]$} & N.S. & $P<0.05$ & - \\
\hline German White-Headed Mutton & De Vries et al., 2004 & [26] & N.S. & N.S. & - \\
\hline Hampshire & Alexander et al., 2005 & {$[2]$} & N.S. & N.S. & - \\
\hline Île-de-France & Vitezica et al., 2005 & {$[83]$} & - & N.S. & - \\
\hline Lacaune & Moussaoui et al. ${ }^{1}$ & & N.S. & - & - \\
\hline Manchega & Moussaoui et al. ${ }^{1}$ & & N.S. & - & - \\
\hline Préalpes du Sud & Vitezica et al., 2005 & {$[83]$} & - & N.S. & - \\
\hline Rambouillet & Alexander et al., 2005 & {$[2]$} & N.S. & N.S. & - \\
\hline Ripollesa sheep & Casellas et al., 2007 & [16] & N.S. & N.S. & - \\
\hline Romanov & Isler et al., 2006 & [46] & N.S. & N.S. & N.S. \\
\hline Scottish Blackface & Sawalha et al., 2007 & {$[74]$} & $P<0.05$ & N.S. & $P<0.05$ \\
\hline \multirow[t]{5}{*}{ Suffolk } & Prokopová et al..$^{5}$ & {$[2]$} & - & N.S. & - \\
\hline & Alexander et al., 2005 & {$[80]$} & N.S. & N.S. & - \\
\hline & Roden et al. ${ }^{6}$ & {$[41]$} & - & N.S. & - \\
\hline & Tongue et al., 2006 & N.S. & - & - & \\
\hline & Hanrahan et al., 2008 & N.S. & N.S. & - & \\
\hline Swaledale & Man et al., 2006 & {$[56]$} & N.S. & $P<0.05$ & N.S. \\
\hline \multirow[t]{4}{*}{ Texel } & Brandsma et al., 2004 & {$[12]$} & - & $P<0.05$ & - \\
\hline & Brandsma et al., 2005 & {$[13]$} & N.S. & N.S. & N.S. \\
\hline & De Vries et al., 2004 & [26] & N.S. & - & - \\
\hline & Hanrahan et al., 2008 & [41] & N.S. & N.S. & - \\
\hline
\end{tabular}

${ }^{\text {a }}$ Growth rate in Isler et al. [46], Vitezica et al., 2006 [84], and De Vries et al. [26].

(3.52 vs. $3.48 \mathrm{~kg}$ ) [74]. In Dorset lambs, carriers of the VRQ allele were $0.6 \mathrm{~kg}$ lighter than ARQ/ARQ lambs [80].

\footnotetext{
${ }^{4}$ Moore R.C., Boulton K., Bishop S.C., Investigating the effect of $\operatorname{Pr} P$ genotype on production traits in Charollais sheep, Proc. BSAS Conference, 2006, p. 1.

${ }^{5}$ Prokopová L., Lewis R.M., Dingwall W.S. et al., Scrapie genotype: an association with lean growth rate, Seventh World Congr. Genet. Appl. Livest. Prod. Montpellier (2002) 31:779-782.

${ }^{6}$ Roden J.A., Haresign W., Analysis of $\mathrm{PrP}$ genotype in relation to performance traits in Suffolk sheep, Proc. Brit. Soc. Anim. Sci., 2001, p. 45.
}

Evidence for significant associations between $\operatorname{Pr} P$ genotype and weaning weight was reported in three studies. German BlackHeaded Mutton sheep heterozygous for the ARR allele grew more slowly (39 g/day less) than non-ARR animals (mean growth rate was $336 \mathrm{~g} /$ day). The effect in the Texel [12] reflected an advantage of about $1 \mathrm{~kg}$ in weight at 135 days (mean $35 \mathrm{~kg}$ ) for VRQ carriers over ARQ*/ARQ*, based on the reported differences in EBV. In the Swaledale breed, ARR carriers (homozygotes and heterozygotes) were heavier than non-ARR carriers at weaning (mean $28.7 \mathrm{~kg}$ ), but only the difference between the ARR heterozygotes and the non-carriers $(0.44 \mathrm{~kg})$ was significant [56]. 
Table III. Association between $\operatorname{Pr} P$ genotype and conformation, ultrasonic muscle and fat depths.

\begin{tabular}{|c|c|c|c|c|c|}
\hline \multirow{2}{*}{ Breed } & \multirow{2}{*}{ Authors } & & \multicolumn{3}{|c|}{ Association with } \\
\hline & & & $\begin{array}{c}\text { Conformation } \\
\text { score }^{\mathrm{a}}\end{array}$ & $\begin{array}{l}\text { Muscle } \\
\text { depth }^{\mathrm{b}}\end{array}$ & $\begin{array}{c}\text { Fat } \\
\text { depth }^{\mathrm{c}}\end{array}$ \\
\hline Blanc du Massif Central & Vitezica et al., 2005 & [83] & - & N.S. & N.S. \\
\hline \multirow[t]{2}{*}{ Charollais } & Hanrahan et al., 2008 & [41] & N.S. & N.S. & \\
\hline & Moore et al. ${ }^{4}$ & & - & $\begin{array}{c}P<0.05 \\
\text { N.S. }\end{array}$ & N.S. \\
\hline Dorset & Isler et al., 2006 & [46] & N.S. & N.S. & N.S. \\
\hline German Black-Headed Mutton & De Vries et al., 2004 & [26] & N.S. & $P<0.05$ & N.S. \\
\hline German White-Headed Mutton & De Vries et al., 2004 & [26] & N.S. & N.S. & N.S. \\
\hline Île-de-France & Vitezica et al., 2005 & [83] & - & N.S. & N.S. \\
\hline INRA 401 & Vitezica et al., 2007 & {$[85]$} & N.S. & N.S. & N.S. \\
\hline Préalpes-du-Sud & Vitezica et al., 2005 & [83] & - & N.S. & N.S. \\
\hline Romanov & Isler et al., 2006 & [46] & N.S. & N.S. & N.S. \\
\hline Scottish Blackface & Sawalha et al., 2007 & [74] & N.S. & N.S. & N.S. \\
\hline \multirow[t]{4}{*}{ Suffolk } & Prokopová et al. ${ }^{5}$ & [26] & - & N.S. & N.S. \\
\hline & De Vries et al., 2004 & & $P<0.05$ & N.S. & N.S. \\
\hline & Roden et al. ${ }^{6}$ & [41] & - & N.S. & N.S. \\
\hline & Hanrahan et al., 2008 & & N.S. & $P<0.05$ & N.S. \\
\hline \multirow[t]{2}{*}{ Texel } & De Vries et al., 2004 & [26] & N.S. & N.S. & N.S. \\
\hline & Hanrahan et al., 2008 & [41] & N.S. & N.S. & N.S. \\
\hline Texel-Booroola & Brandsma et al., 2005 & [13] & N.S. & N.S. & N.S. \\
\hline
\end{tabular}

${ }^{a}$ Refers to carcass assessments in the studies of Isler et al. (leg score) [46], Sawalha et al. [74], Hanrahan et al. [41], Vitezica et al., 2007 (carcass conformation) [85], and live animal assessments in the case of De Vries et al. [26] and Brandsma et al. [13].

b Ultrasonic muscle depth of live animals in all cases except Isler et al. [46], and Vitezica et al., 2007 [85], who used depth and area, respectively, of the longissimus dorsi muscle measured on the carcass.

${ }^{c}$ Ultrasonic fat depth of live animals was used by all authors except Isler et al. [46], and Vitezica et al. [85], who used carcass back fat depth.

The effects on slaughter weight (mean $39.7 \mathrm{~kg}$ ) in Scottish Blackface lambs reflected the finding that heterozygous AHQ lambs were heavier $(0.5 \mathrm{~kg})$ at slaughter than nonAHQ carriers and ARQ homozygotes were lighter $(0.4 \mathrm{~kg})$ than either ARQ heterozygous animals or non-ARQ animals [74].

Of the almost 50 comparisons in Table II, only six were statistically significant and given that in most studies multiple comparisons were involved the base number of actual tests is of the order of at least 100 . Thus, the observed number of significant results is approaching the expected type I error rate. The overall conclusion from the studies summarised in Table II is that there is no compelling evidence to reject the null hypothesis that there is no association between $\operatorname{PrP}$ genotype and lamb growth traits.

\subsubsection{Carcass conformation and composition}

Parry [67] suggested that the conformation of scrapie susceptible animals was superior to that of scrapie resistant animals. Further concerns that $\operatorname{PrP}$ genotype could be associated with muscularity were raised following the observation that a line of sheep that was selected for increased lean tissue growth rate had a much higher rate of scrapie than an unselected control line [45]. The selection line had a higher frequency of QQ171 animals than the control line. It therefore was possible that this reflected a genetic association between scrapie susceptibility and lean tissue growth rate. However, as the study was not designed to test this hypothesis it was suggested [45] that the association might simply have been a consequence of founder effects on gene frequency at the $\operatorname{Pr} P$ locus. 
Table IV. Association between $\operatorname{Pr} P$ genotype and carcass composition traits.

\begin{tabular}{|c|c|c|c|c|c|c|}
\hline \multirow{2}{*}{ Breed } & \multirow{2}{*}{ Authors } & & \multicolumn{4}{|c|}{ Association with } \\
\hline & & & $\begin{array}{l}\text { Muscle } \\
\text { weight }^{\text {a }}\end{array}$ & $\begin{array}{c}\text { Fat } \\
\text { weight }\end{array}$ & $\begin{array}{c}\text { Internal fat } \\
\text { weight }^{\mathrm{b}}\end{array}$ & $\begin{array}{l}\text { Lean growth } \\
\text { rate }^{c}\end{array}$ \\
\hline Romanov & Isler et al., 2006 & [46] & N.S. & N.S. & N.S. & - \\
\hline Dorset & Isler et al., 2006 & [46] & N.S. & N.S. & N.S. & - \\
\hline INRA 401 & Vitezica et al., 2007 & [85] & - & - . & N.S. & - \\
\hline Scottish Blackface & Sawalha et al., 2007 & [74] & N.S. & N.S. & N.S. & - \\
\hline Suffolk & Prokopová et al. ${ }^{5}$ & & - & - & - & N.S. \\
\hline & Roden et al. ${ }^{6}$ & & - & - & - & N.S. \\
\hline
\end{tabular}

${ }^{a}$ Protein weight for Isler et al. [46].

${ }^{\mathrm{b}}$ Kidney fat score for Vitezica et al. [85].

${ }^{c}$ Breeding value for lean tissue growth rate based on an index combining information on live weight, and ultrasonic muscle and fat depths at 120 days of age.

The evidence from studies that involved evaluation of conformation and related measures such as muscle and fat depth are summarised in Table III, while carcass composition data are summarised in Table IV. The significant effect on conformation in the Suffolk reflected a higher score in ARR homozygotes than in ARR heterozygotes [26], but there was no difference between ARR homozygotes and animals without an ARR allele.

With regard to muscle depth, German Black-Headed Mutton animals carrying the ARR allele had a smaller muscle depth than non-ARR animals [26]. Hanrahan et al. [41] reported that the ARR allele increased muscle depth relative to ARQ in Charollais breed but the difference between these alleles was in the opposite direction in the Suffolk breed. The apparent effect in the Charollais was not confirmed by the results of Moore et al. ${ }^{4}$. There was no evidence for a significant association in other Suffolk populations $s^{5,6}$. In both these studies, however, animals homozygous for the $\mathrm{R}_{171}$ codon had a numerically smaller muscle depth than animals that were $\mathrm{Q}_{171}$ homozygotes - the same direction as in Hanrahan et al. [41]. It must be pointed out, however that the number of sires in the latter study was modest and the significant effects need to be judged alongside the evidence based on much larger numbers from the other studies of the Charollais and Suffolk breeds.

The ARR allele has been associated with a longer carcass in the Romanov breed, but not in the Dorset breed [46]. These authors have also reported that a quantitative trait locus (QTL) for metacarpal length is located close to the $\operatorname{Pr} P$ gene (unpublished data, cited in [46]). In East Friesian milk sheep, ARR/ARR animals had a significantly lower withers height than ARR heterozygotes and ARQ/ARQ animals, and there was also evidence that rump height was negatively associated with ARR/ARR genotype [28]. It may be argued that there is a gene located on sheep chromosome 13 with an effect on skeletal dimensions (which could cause reduced muscularity due to the fact that muscles are stretched over a greater area). However, there was no evidence for any association between $\operatorname{PrP}$ genotype and either carcass width or length in the INRA 401 breed [85]. If there is a locus affecting skeletal size close to the $\operatorname{Pr} P$ locus then this would provide a scientific basis for the belief held by many sheep breeders that $\operatorname{Pr} P$ genotype is associated with muscularity/conformation. The evidence summarised above does not provide any substantial support for such a hypothesis.

The only reported studies involving carcass composition are $[46,74]$. In the case of Sawalha et al. [74] composition was estimated from computerised tomography using validated prediction procedures. Two studies that indirectly evaluated lean tissue growth ${ }^{5,6}$ are also relevant. The principal results from these studies are summarised in Table V. None of the traits listed in this table were associated 
Table V. Association between $\operatorname{Pr} P$ genotype and milk production traits.

\begin{tabular}{lccccc}
\hline \multirow{2}{*}{ Breed } & Authors & \multicolumn{3}{c}{ Association with } \\
\cline { 4 - 6 } & & & Milk yield (kg) & Fat (\%) & Protein (\%) \\
\hline Churra & Álvarez et al., 2006 & {$[3]$} & N.S. & N.S. & N.S. \\
Lacaune $^{\text {a }}$ & Barillet et al. & & N.S. & N.S. & N.S. \\
East Friesian Milk Sheep $_{\text {Sardinian }}$ & De Vries et al., 2006 & {$[28]$} & N.S. & N.S. & N.S. \\
& Salaris et al., 2007 & {$[72]$} & N.S. & - & - \\
\hline
\end{tabular}

${ }^{\text {a }}$ From a grand-daughter design involving 11 Lacaune sires, 3 Basco-Bernaise sires, and 1 Manech sire.

with $\operatorname{PrP}$ genotype. Results for a large number of carcass variables were reported by Isler et al. [46], but the only significant association was for marbling score of the longissimus dorsi muscle - a lower marbling score was associated with the ARR allele in the Romanov breed $(P<0.05)$.

\subsection{Association between the $\operatorname{Pr} P$ gene and milk production traits}

The available evidence of an association between $\operatorname{PrP}$ and milk production and composition is summarised in Table V. There was no indication in any of the populations studied that there was an association between $\operatorname{Pr} P$ genotype and milk yield, percentage fat, or percentage protein. Similarly, there was no evidence for an association between $\operatorname{PrP}$ genotype and the udder morphology traits: teat position, degree of udder suspension, udder depth, and degree of separation of two udder halves [72].

\subsection{Association between the $\operatorname{Pr} P$ gene and wool quality}

Information on wool quality is limited to a small number of studies. There was no evidence for any association between wool quality score and $\operatorname{Pr} P$ genotype in either Suffolk, Texel, German White-Headed Mutton, German Black-Headed Mutton, or East Friesian populations [26, 27]. Similarly there was no association between $\operatorname{PrP}$ genotype and fibre diameter or staple length in the INRA 401

\footnotetext{
${ }^{7}$ Barillet F., Andréoletti O., Palhiere I. et al., Breeding for scrapie resistance using $\operatorname{Pr} P$ genotyping in the French dairy sheep breeds, 7th World Congress on Genetics Applied to Livestock Production, 2002, Montpellier, France, 31:683-686.
}

breed [85] though one QTL affecting mean fibre diameter (OAREA16, see Fig. 1) was identified in close proximity to the prion protein gene. Of interest, however, is the evidence of a relationship between $\operatorname{PrP}$ genotype and coat colour in Soay and Shetland sheep ${ }^{8}$.

\subsection{Association between the $\operatorname{Pr} P$ gene and disease traits}

The number of studies exploring the relationship between $\operatorname{PrP}$ genotype and disease traits is too few to form any definitive opinion on whether there is any likelihood that capacity to cope with disease is associated with $\operatorname{PrP}$ genotype. The reported studies are presented below.

\subsubsection{Mastitis/somatic cell counts}

The abnormal form of the prion protein $\left(\mathrm{PrP}^{\mathrm{Sc}}\right)$ can be routinely detected in follicular dendritic cells in the spleen, tonsils, and lymph nodes of scrapie-infected sheep. Furthermore, $\mathrm{PrP}^{\mathrm{Sc}}$ was associated with lymphoid follicles from the mammary gland of four mastitic ewes with clinical scrapie, but was not detected in scrapie affected non-mastitic ewes [51]. Hence there is a concern that $\mathrm{PrP}^{\mathrm{Sc}}$ could be detected in milk of animals with high somatic cell counts in milk or suffering from mastitis. However, no association was detected between $\operatorname{PrP}$ genotype and milk somatic cell score in East Friesian sheep [27] or in the Churra breed [3].

\footnotetext{
${ }^{8}$ Bell L., Goodman T., Martin J.H. et al., A survey of scrapie $\operatorname{Pr} P$ genotype results and their relationships with coat colour and hornedness in selected UK rare sheep breeds, Proc. of the British Society of Animal Science, 2005, p. 124.
} 


\section{$\underline{0-50 \mathrm{cM}}$}



$\underline{\mathbf{5 0 - 1 0 0 c M}}$

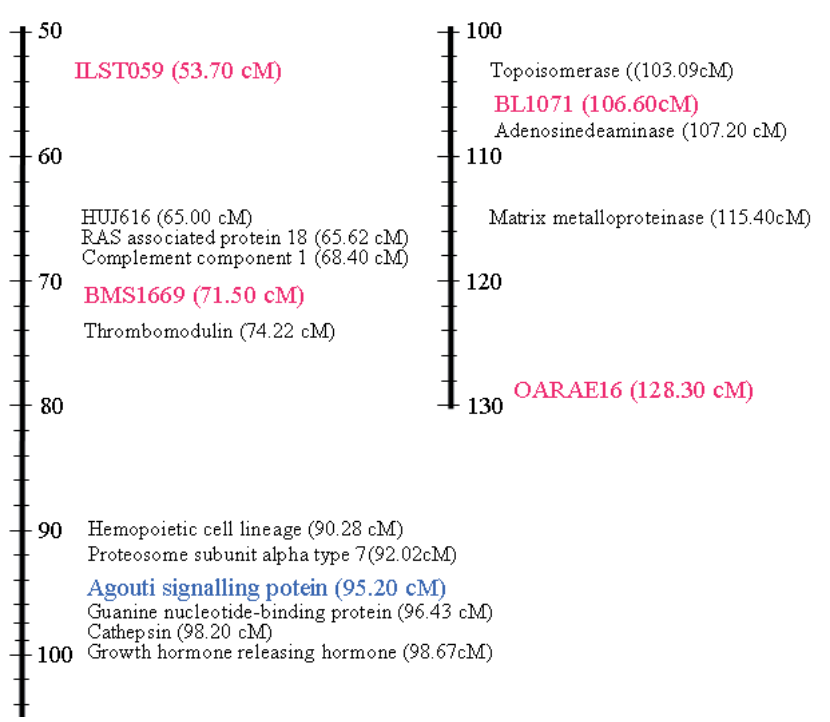

\section{$\underline{100-150 \mathrm{cM}}$}

Figure 1. Location of genes and quantitative trait loci (QTL) on chromosome 13 (modified from Sheep LDB integrated map V4.1, AnimalQTLdb, www.animalgenome.org/QTLdb [consulted 15 January 2008]).

\subsubsection{Resistance to Salmonella}

The only reported study on the potential association between $\operatorname{PrP}$ genotype and bacterial infection suggests that there is no association between $\operatorname{Pr} P$ genotype and experimental intravenous inoculation with Salmonella abortusovis [85].

\subsubsection{Gastrointestinal nematodes}

A QTL located close to the $\operatorname{PrP}$ gene is associated with resistance to gastrointestinal nematode infection (marker ILST059 [86], see Fig. 1). This raises the possibility of an association between this locus and parasite resistance. There appears to be no studies on the relationship between $\operatorname{PrP}$ genotype and parasite resistance. It is worth noting that gastrointestinal nematode infection hastens the onset of the clinical signs of scrapie [39].

\subsubsection{Atypical scrapie}

There is substantial evidence to suggest that there are a variety of strains of "atypical scrapie" present in ruminants [6]. Disease progression after infection with these strains does not follow the association patterns established between classical scrapie and the $\operatorname{Pr} P$ alleles described in Section 1. In fact evidence suggests that the VRQ allele is associated with resistance [32,73] and the AHQ, $A F^{141} R Q$, and ARR alleles are associated with susceptibility to atypical scrapie $[61,73]$. What is of greatest concern is that sheep of the ARR/ARR genotype can be naturally $[32,49]$ and experimentally [15] infected with atypical scrapie and can transmit the disease to mice [49]. Hence there is a concern that selection for alleles that are associated with resistance to classical scrapie could result in sheep populations that are susceptible to atypical scrapie. However, there is no evidence that atypical scrapie has any of the potential human health effects associated with BSE.

\section{POTENTIAL FOR GENE LINKAGE WITH THE PrP GENE ON CHROMOSOME 13}

From the large number of studies reviewed above, it can be concluded that there is no convincing evidence for an association between $\operatorname{PrP}$ alleles and the performance traits routinely measured in sheep. However, we must 
ask ourselves have we been looking at the traits that are most likely to be affected. In this section, an alternative approach is employed whereby information is obtained from the sheep chromosome map for genes or QTL that are linked with the prion protein gene and the traits that could be affected are highlighted. A diagrammatic representation of the LDB integrated map for sheep chromosome 13 , showing the location of the prion protein gene and the relative location of other known protein expressing genes on this chromosome, is presented in Figure 1. A number of microsatellites that are referred to in the literature are also identified giving their relative location to the prion protein gene.

In an attempt to identify traits that maybe associated with the prion protein gene, two approaches can be taken. Firstly, information from QTL studies can be analysed to identify if any QTL on chromosome 13 have been associated with performance traits. Secondly, we can speculate about the potential role of known genes on chromosome 13. A total of 51 QTL are described in the sheep database "SheepQTLdb" ; 2 of these are associated with immune function, 21 with parasite resistance, 1 with skeletal abnormality, 4 with coat colour, 2 with fibre, 9 with fleece, 1 with mastitis, 2 with milk protein, 8 with reproduction, and 1 with horn growth. Two of these QTL are located on chromosome 13 - both are associated with coat pattern and are in proximity to the Agouti locus [9]. A further QTL has recently been identified on chromosome 13 that is associated with wool fibre diameter (at $110 \mathrm{cM}$ ) and another that is indirectly associated with resistance to Salmonella infection (at $36 \mathrm{cM}$ ) [85].

Based on the list of known genes on chromosome 13 , it can be hypothesised that the following traits may be affected if a polymorphic gene was in linkage disequilibrium with the prion protein gene.

\subsection{Growth and obesity traits}

Growth hormone releasing hormone (GHRH), a peptide hormone produced in the

\footnotetext{
${ }^{9}$ http://sphinx.vet.unimelb.edu.au/QTLdb/ [consulted November 2007].
}

hypothalamus, regulates the synthesis and release of growth hormone from the pituitary gland and thus might be expected to influence growth traits. The absence of any association between growth traits and $\operatorname{Pr} P$ genotype (Section 2) suggests that the $\operatorname{Pr} P$ gene is in linkage equilibrium with the GHRH gene, or that the GHRH gene is not polymorphic.

There are, however, two genes located on chromosome 13 that have been implicated in obesity. These are the Guanine nucleotide binding protein (GNAS1) gene and the Agouti signalling protein (ASIP) gene. The GNAS1 gene encodes the alpha subunit of the G stimulatory protein (Gs). Obesity is frequently associated with $\mathrm{G}$ protein variants [48]. GNAS1 is thought to be an imprinted gene $[54,58]$. While the ASIP gene encodes a paracrinesignaling molecule that causes hair follicle melanocytes to synthesize the yellow pigment, phaeomelanin, pleiotropic effects of this gene are known to include adult-onset obesity [86]. This is of particular interest following the observation that there is a relationship between $\operatorname{PrP}$ genotype and coat colour (which would most likely be under the control of the Agouti locus) in Soay and Shetland sheep ${ }^{6}$. Hence, an analysis on the relationship between $\operatorname{PrP}$ alleles and mature body weight and composition of sheep would be of interest.

\subsection{Maternal traits}

Based on the known gene list for chromosome 13 , it can be hypothesised that the following maternal traits may be affected if one of these genes was polymorphic and in linkage disequilibrium with the prion protein gene:

- Mammary gland differentiation and maternal care: two genes on chromosome 13 are involved with mammary gland differentiation and two are involved with behaviour. Mammary gland differentiation is under the direct regulation of oxytocin, and indirect regulation of Integrin- $\beta 1$, which plays a permissive role in the prolactin signalling of mammary gland differentiation [62]. Acute reproductive smooth muscle responses, such as uterine contractions during labour and milk letdown during 
lactation, are also regulated by oxytocin [68]. Finally, both arginine vasopressin and oxytocin modulate a range of social behaviours including social recognition, bonding, and parental care [52]. Thus there is potential association between $\operatorname{Pr} P$ alleles and mammary gland development, lactation, and social care of the offspring.

- Uterine function: various aspects of uterine functionality are influenced by a number of genes on chromosome 13. The uterus is a particularly dynamic organ with major changes in cellular structure and function during the periods of puberty, throughout the oestrous cycle, during pregnancy, and in the postpartum period. Genes such as CENPB, MMP9, and OXY are known to influence aspects of uterine function. CENPB null mice have reduced body weight and reduced uterine weight [35]. Histology of the uterus revealed normal myometrium and endometrium but grossly disrupted luminal and glandular epithelium. Oxytocin plays a fundamental role in uterine contractions during parturition. Finally, the matrix metalloproteinases including MMP9 are involved in the breakdown of the extracellular matrix in normal physiological processes such as the tissue remodelling events occurring throughout the oestrous cycle, pregnancy, and in the postpartum period. The fact that there are no observed relationships between $\operatorname{Pr} P$ genotype and litter size or embryo survival suggest that there is no association between $\operatorname{Pr} P$ alleles and normal variation in uterine function, though there is no evidence in the literature that the direct comparison has been made.

\subsection{Immune traits}

There are a number of genes located on chromosome 13 that influence the functioning of monocytes/macrophages, in both apoptotic and infective states, as well as T-cells. Three genes, expressed in T-cells and monocytes, are involved in the cytokine pro-inflammatory immune pathway. IL2RA is a precursor type I membrane protein that transduces the IL-2 signal (a T-cell growth factor). As most pe- ripheral as well as thymic T-cells do not carry the receptor in vivo, the regulated expression of IL2RA appears to be a safeguard against a catastrophic spread of $\mathrm{T}$-cell proliferation by an immunogenic stimulus. Semaphorin 7A, which is expressed on activated T-cells, stimulates cytokine production in monocytes and macrophages through ITGb1, and is critical for the effector phase of the inflammatory immune response [75]. Monocyte-derived macrophages were observed to secrete vimentin (VIM) in vitro and secretion was enhanced by the pro-inflammatory cytokine tumour necrosis factor (TNF)- $\alpha$ and inhibited by the anti-inflammatory cytokine IL-10 [59]. There are very few studies in the literature exploring the possibility that selection for specific $\operatorname{PrP}$ alleles could affect the immune response following an infection. Clearly, the known functions of the genes listed above suggest that more specific studies on bacterial, viral, and parasitological infections are warranted in relation to possible associations with $\operatorname{PrP}$ genotype.

\subsection{Apoptosis/phagocytosis}

Apoptosis is involved in a range of normal tissue processes such as mammary gland and uterine involution, epithelial cell regeneration in the digestive tract and spermatogenesis. Apoptosis is also fundamental to a variety of disease processes and has been detected in the pathology of a variety of infectious diseases such as Maedi-Visna [30] and scrapie [33].

There are four known genes on chromosome 13 that are involved in apoptotic and phagocytotic pathways. BCL2-like 1 is a key regulator of apoptosis. $\mathrm{C} 1 \mathrm{QR} 1$ is a transmembrane glycoprotein expressed on monocytes, neutrophils, endothelial cells, and stem cells that has been implicated in the regulation of cell-cell interactions and in the efficiency of phagocytosis. Cathepsin B is a normal lysosomal proteinase that is localized primarily in lysosomes or endosomes, but translocated to the cytosol during apoptosis. The translocation allows these proteases to interact with caspases and other apoptotic signalling mechanisms. PSMA7 is an essential component of the ATP-dependent proteolytic pathway in 
Table VI. Summary of the known protein functions of genes on sheep chromosome 13.

\begin{tabular}{|c|c|c|}
\hline Gene & Protein product & Known protein function \\
\hline OXT & Oxytocin & Uterine contractions during labour, milk letdown \\
\hline AVP & Vasopressin & Social recognition, bonding, parental care \\
\hline VIM & Vimentin & Maintains cell integrity, can be modulated by cytokines \\
\hline IL2RA & IL2 receptor $\alpha$ & Transduces the IL-2 cytokine signal \\
\hline ITPA & Inosine triphosphatease & Catabolism of inosine triphosphate \\
\hline CENBP & Centromeric protein $\mathrm{B}$ & A major chromosomal centromeric protein \\
\hline ITGb1 & Integrin beta- 1 & $\begin{array}{l}\text { Part of the cytokine synthesis pathway endochondral bone for- } \\
\text { mation permissive role in prolactin signalling for mammary } \\
\text { gland differentiation }\end{array}$ \\
\hline HAP & Haptoglobin & $\begin{array}{l}\text { Binds haemoglobin }(\mathrm{Hb}) \text { to prevent } \mathrm{Hb} \text {-induced oxidative tis- } \\
\text { sue damage, acute phase protein }\end{array}$ \\
\hline C1QR1 & $\begin{array}{l}\text { Complement component } 1 \mathrm{q} \\
\text { subcomponent receptor } 1\end{array}$ & $\begin{array}{l}\text { Transmembrane glycoprotein expressed on monocytes, neu- } \\
\text { trophils, endothelial cells. Involved with cell-cell interactions } \\
\text { and in the efficiency of phagocytosis }\end{array}$ \\
\hline \multirow[t]{2}{*}{ THBD } & Thrombomodulin & $\begin{array}{l}\text { An endothelial cell surface glycoprotein that forms a complex } \\
\text { with thrombin }\end{array}$ \\
\hline & BCL2-like 1 & Regulator of programmed cell death (apoptosis) \\
\hline $\mathrm{HCK}$ & Hemopoietic cell kinase & $\begin{array}{l}\text { Protein-tyrosine kinase prominent in mature granulocytes and } \\
\text { monocytes }\end{array}$ \\
\hline PSMA7 & Proteasome subunit, $\alpha$-type 7 & $\begin{array}{l}\text { An essential component of the ATP-dependent proteolytic } \\
\text { pathway }\end{array}$ \\
\hline ASIP & Agouti signalling protein & $\begin{array}{l}\text { A paracrine signalling molecule that causes hair follicle } \\
\text { melanocytes to synthesize phaeomelanin. Pleiotropic effects } \\
\text { of this gene include adult-onset obesity, increased tumor sus- } \\
\text { ceptibility, and premature infertility }\end{array}$ \\
\hline GNAS1 & $\begin{array}{l}\text { Guanine nucleotide binding } \\
\text { protein }\end{array}$ & $\begin{array}{l}\text { G proteins are essential to intracellular cell signalling path- } \\
\text { ways }\end{array}$ \\
\hline CTSB & Cathepsin B & A lysosomal proteinase that is expressed in all cells \\
\hline GHRH & $\begin{array}{l}\text { Growth hormone releasing } \\
\text { hormone }\end{array}$ & Stimulates growth hormone production and secretion \\
\hline TOP1 & Topoisomerase & Essential for DNA-topology modulation \\
\hline L3MBTL & & Coordinates patterns of gene activity \\
\hline ADA & Adenosine deaminase & An enzyme involved in purine metabolism \\
\hline MMP9 & Matrix metalloproteinase 9 & $\begin{array}{l}\text { Involved in the breakdown of extracellular matrix in nor- } \\
\text { mal physiological processes, such as embryonic development, } \\
\text { reproduction, and tissue remodelling, as well as in disease pro- } \\
\text { cesses }\end{array}$ \\
\hline
\end{tabular}

eukaryotic cells and is responsible for the degradation of most cellular proteins. Proteasomes are distributed throughout eukaryotic cells at a high concentration and cleave peptides in an ATP/ubiquitin-dependent process in a non-lysosomal pathway. Phosphorylation of PSMA7 regulates proteasome activity [55].

\subsection{General cell function}

The remaining known genes on chromosome 13 play a wide variety of roles in general cellular function and metabolism. A brief summary of their known functions in the cell is presented in Table VI.

\section{CONCLUSIONS}

Given the extensive studies on a wide range of production traits that are important to the productivity and profitability of sheep production enterprises, and the marked absence of significant associations with $\operatorname{PrP}$ genotype (Section 2), it seems reasonable to conclude 
that there is no compelling evidence that selection for scrapie resistance will have any direct negative impact on the most commonly measured performance traits.

In contrast, the number of studies involving health/disease traits and survival/longevity are very few. Considering that a number of genes on chromosome 13 are involved in apoptosis, phagocytosis, and immune regulation, it seems prudent to suggest that further studies on the relationship between traits such as susceptibility to bacterial (mastitis, foot rot), viral (Maedi-Visna), and parasitological (liver fluke and a variety of locally relevant gastrointestinal nematodes) infections are warranted. Given that genes on chromosome 13 are also involved in general cellular function, and potentially late onset obesity, studies on lamb survival and longevity are also warranted. Of course the proximity of such genes to the $\operatorname{PrP}$ locus will determine any implications for programmes to select for increased resistance to scrapie and thus an important immediate issue is improvement in the precision of the sheep genome map.

\section{REFERENCES}

[1] Acutis P.L., Sbaiz L., Verburg F., Runa M.V., Ru G., Moda G., et al., Low frequency of the scrapie resistance-associated allele and presence of lysine-171 allele of the prion protein gene in Italian Biellese ovine breed, J. Gen. Virol. (2004) 85:3165-3172.

[2] Alexander B.M., Stobart R.H., Russell W.C., O'Rourke K.I., Lewis G.S., Logan J.R., et al., The incidence of genotypes at condon 171 of the prion protein gene (PRNP) in five breeds of sheep and production traits of ewes associated with those genotypes, J. Anim. Sci. (2005) 83:455-459.

[3] Álvarez L., Gutierrez-Gil B., San Primitovo F., de la Fuente L.F., Arranz J.J., Influence of prion genotype on milk production traits in Spanish Churra sheep, J. Dairy Sci. (2006) 89:1784-1791.

[4] Antoine N., Cesbron J.Y., Coumans B., Jolois O., Zorzi W., Heinen E., Differential expression of cellular prion protein on human blood and tonsil lymphocytes, Haematologica (2000) 85:475-480.

[5] Arnold M., Meek C., Webb C.R., Heinville L.J., Assessing the efficacy of a ram-genotyping programme to reduce susceptibility to scrapie in Great Britain, Prev. Vet. Med. (2002) 56:227-249.

[6] Baron T., Biacabe A.G., Arsac J.N., Benestad S., Groschup M.H., Atypical transmissible spongiform encephalopathies (TSEs) in ruminants, Vaccine (2007) 25:5625-5630.
[7] Baylis M., Chihota C.M., Stevenson E., Goldmann W., Smith A., Sivam K., et al., Risk of scrapie in British sheep of different prion protein genotype, J. Gen. Virol. (2004) 85:2735-2740.

[8] Belt P.B.G.M., Muileman I.H., Schreuder B.E.C., Bos-De Ruijter J., Gielkens A.L.J., Smits M.A., Identification of five allelic variants of the sheep $\operatorname{PrP}$ gene and their association with natural scrapie, J. Gen. Virol. (1995) 76:509-517.

[9] Beraldi D., McRae A.F., Gratten J., Slate J., Visscher P.M., Pemberton J.M., Development of a linkage map and mapping of phenotypic polymorphisms in a free-living population of Soay sheep (Ovis aries), Genetics (2006) 173:1521-1537.

[10] Vitezica Z., Bodin L., Bonnet E., Elsen J.M., A study on the relationship between the $\operatorname{Pr} P$ gene and the fertility of Lacaune rams, ITEA Producción Animal (2004) 100:151-155.

[11] Bindon B.M., Piper L.R., Hillard M.A., Reproductive physiology and endocrinology of prolific sheep, in: Fahmy M.H. (Ed.), Prolific sheep, CAB International Oxon, Cambridge, UK, 1996, pp. 453-469.

[12] Brandsma J.H., Janss L.L.G., Visscher A.H., Association between $\operatorname{Pr} P$ genotypes and litter size and 135 days weight in Texel sheep, Livest. Prod. Sci. (2004) 85:59-64.

[13] Brandsma J.H., Janss L.L.G., Visscher A.H., Association between $\operatorname{Pr} P$ genotypes and performance traits in an experimental Dutch Texel herd, Livest. Prod. Sci. (2005) 95:89-94.

[14] Bruce M.E., Boyle A., Cousens S., McConnell I., Foster J., Goldmann W., et al., Strain characterization of natural sheep scrapie and comparison with BSE, J. Gen. Virol. (2002) 83:695-704.

[15] Buschmann A., Luhken G., Schultz J., Erhardt G., Groschup M.H., Neuronal accumulation of abnormal prion protein in sheep carrying a scrapie-resistant genotype ( $\left.\operatorname{Pr} P^{A R R / A R R}\right)$, J. Gen. Virol. (2004) 85:27272733.

[16] Casellas J., Caja G., Bach R., Francino O., Piedrafita J., Association analyses between the prion protein locus and reproductive and lamb weight traits in Ripollesa sheep, J. Anim. Sci. (2007) 85:592-597.

[17] Castiglioni B., Comincini S., Drisaldi B., Motta T., Ferretti L., Comparative mapping of the prion gene (PRNP) locus in cattle, sheep and human with PCRgenerated probes, Mamm. Genome (1998) 9:853-855.

[18] Chase-Topping M.E., Kruuk L.E.B., Lajous D., Touzeau S., Matthews L., Simm G., et al., Genotypelevel variation in lifetime breeding success, litter size and survival of sheep in scrapie-affected flocks, J. Gen. Virol. (2005) 86:1229-1238.

[19] Davis G.H., McEwan J.C., Fennessy P.F., Dodds K.G., Farquhar P.A., Evidence for the presence of a major gene influencing ovulation rate on the $\mathrm{X}$ chromosome of sheep, Biol. Reprod. (1991) 44:620624. 
[20] Davis G.H., Dodds K.G., Wheeler R., Jay N.P., Evidence that an imprinted gene on the $\mathrm{X}$ chromosome increases ovulation rate in sheep, Biol. Reprod. (2001) 64:216-221.

[21] Davis G.H., Galloway S.M., Ross I.K., Gregan S., Ward J., Nimbkar B.V., et al., DNA tests in prolific sheep from eight countries provide new evidence on origin of the Booroola (FecB) mutation, Biol. Reprod. (2002) 66:1869-1874.

[22] Davis G.H., Major genes affecting ovulation rate in sheep, Genet. Sel. Evol. (2005) 37:S11-S23.

[23] Dawson M., Hoinville L.J., Hosie B.D., Hunter N., Guidance on the use of $\operatorname{PrP}$ genotyping as an aid to the control of clinical scrapie, Vet. Rec. (1998) 142:623-625.

[24] Dawson M., Moore R.C., Bishop S.C., Progress and limits of $\operatorname{PrP}$ gene selection policy, Vet. Res. (2008) 39:25.

[25] De Vries F., Hamann H., Drögemüller C., Ganter M., Distl O., Analysis of associations between the prion protein genotype and reproduction traits in meat sheep breeds, Anim. Sci. (2004) 79:397-404.

[26] De Vries F., Borchers N., Hamann H., Drögemüller C., Reinecke S., Lüpping W., et al., Associations between the prion protein genotype and performance traits of meat breeds of sheep, Vet. Rec. (2004) 155:140-143.

[27] De Vries F., Hamann H., Drögemüller C., Ganter M., Disti O., Analysis of associations between the prion protein genotypes and production traits in East Friesian milk sheep, J. Dairy Sci. (2005) 88:392-398.

[28] De Vries F., Hamann H., Drögemüller C., Ganter M., Distil O., Asssociations between the prion protein genotype and type traits in East Friesian milk sheep, Vet. Rec. (2006) 158:849-852.

[29] Drogemuller C., Leeb T., Distl O., $\operatorname{PrP}$ genotype frequencies in German breeding sheep and the potential to breed for resistance to scrapie, Vet. Rec. (2001) 149:349-352.

[30] Duval R., Delebassee S., Cardot P.J., Bosgiraud C., Visna virus-induced cytopathic effect in vitro is caused by apoptosis, Arch. Virol. (2002) 147:943-959.

[31] Elsen J.M., Amigues Y., Schelcher F., Ducrocq V., Andréoletti O., Eychenne F., et al., Genetic susceptibility and transmission factors in scrapie: detailed analysis of an epidemic in a closed flock of Romanov, Arch. Virol. (1999) 144:431-445.

[32] Everest S.J., Thorne L., Barnicle D.A., Edwards J.C., Elliott H., Jackman R., et al., Atypical prion protein in sheep brain collected during the British scrapie-surveillance programme, J. Gen. Virol. (2006) 87:371-477.

[33] Fairbairn D.W., Carnahan K.G., Thwaits R.N., Grigsby R.V., Holyoak G.R., O’Neill K.L., Detection of apoptosis induced DNA cleavage in scrapie-infected sheep brain, FEMS Microbiol. Lett. (1994) 115:341346.
[34] Foster J.D., Parnham D., Chong A., Goldmann W., Hunter N., Clinical signs, histopathology and genetics of experimental transmission of BSE and natural scrapie to sheep and goats, Vet. Rec. (2001) 148:165171.

[35] Fowler K.J., Hudson D.F., Salamonsen L.A., Edmondson S.R., Earle E., Sibson M.C., et al., Uterine dysfunction and genetic modifiers in centromere protein B-deficient mice, Genome Res. (2002) 10:30-41.

[36] Galloway S.M., McNatty K.P., Cambridge L.M., Laitinen M.P.E., Juengel J.L., Jokiranta T.S., et al., Mutations in an oocyte-derived growth factor gene (BMP15) cause increased ovulation rate and infertility in a dosage-sensitive manner, Nat. Genet. (2000) 25:279-283.

[37] Goldmann W., O’Neill G., Cheung F., Charleson F., Hunter N., $\operatorname{PrP}$ (prion) gene expression in sheep may be modulated by alternative polyadenylation of its messenger RNA, J. Gen. Virol. (1999) 80:2275-2283.

[38] Groschup M.H., Lacroux C., Buschmann A., Lunken G., Mathey J., Eiden M., et al., Classic scrapie in sheep with the ARR/ARR prion genotype in Germany and France, Emerging Infect. Dis. (2007) 13:1201-1207.

[39] Gruner L., Elsen J.M., Vu Tien Khang J., Eychenne F., Caritez J.C., Jacquiet P., et al., Nematode parasites and scrapie: experiments in sheep and mice, Parasitol. Res. (2004) 93:493-498.

[40] Hanrahan J.P., Gregan S.M., Mulsant P., Mullen M., Davis G.H., Powell R., et al., Mutations in the genes for oocyte-derived growth factors GDF9 and BMP15 are associated with both increased ovulation rate and sterility in Cambridge and Belclare sheep (Ovis aries), Biol. Reprod. (2004) 70:900-909.

[41] Hanrahan J.P., Casey K.C., Sweeney T., Evidence for a breed specific association between $\operatorname{Pr} P$ genotype and ultrasonic muscle depth but not for survivability, growth or carcass traits in sheep, Livest. Sci., in press.

[42] Houston F., Goldmann W., Chong A., Jeffrey M., Gonzalez L., Fosten J., et al., Prion disease: BSE in sheep bred for resistance to infection, Nature (2003) 423:498.

[43] Hu W., Rosenberg R.N., Stüve O., Prion proteins: a biological role beyond prion diseases, Acta. Neurol. Scand. (2007) 116:75-82.

[44] Hunter N., Foster J.D., Goldmann W., Stear M.J., Hope J., Bostock C., Natural scrapie in a closed flock of Cheviot sheep occurs only in specific $\operatorname{Pr} P$ genotypes, Arch. Virol. (1996) 141:809-924.

[45] Hunter N., Moore L., Hosie B.D., Dingwall W.S., Greig A., Association between natural scrapie and $\operatorname{Pr} P$ genotype in a flock of Suffolk sheep in Scotland, Vet. Rec. (1997) 140:59-63.

[46] Isler B.J., Freking B.A., Thallman R.M., Heaton M.P., Leymaster K.A., Evaluation of associations between prion haplotypes and growth, carcass, and meat quality traits in a Dorset $\times$ Romanov sheep population, J. Anim. Sci. (2006) 84:783-788. 
[47] Kao R.R., Gravenor M.B., Baylis M., Bostock C.J., Chihota C.M., Evans J.C., et al., The potential size and duration of an epidemic of bovine spongiform encepholopathy in British sheep, Science (2002) 295:332-335.

[48] Lania A.G., Mantovani G., Spada A., Mechanisms of disease: Mutations of $G$ proteins and G-protein-coupled receptors in endocrine diseases, Nat. Clin. Pract. Endocrinol. Metab. (2006) 2:681-693.

[49] Le Dur A., Beringue V., Andréoletti O., Reine F., Lan Lai T., Baron T., et al., A newly identified type of scrapie agent can naturally infect sheep with resistant PrP genotypes, Proc. Natl. Acad. Sci. USA (2005) 102:16031-16036.

[50] Lee I.Y., Westaway D., Smit A.F.A. Wang K., Seto J., Chen L., et al., Complete genomic sequence and aznalysis of the prion protein gene region from three mammalian species, Genome Res. (1998) 8:1022-1037.

[51] Ligios C., Sigurdson C.J., Santucciu C., Carcassola G., Manco G., Basagni M., et al., $\operatorname{Pr} P^{\mathrm{Sc}}$ in mammary glands of sheep affected by scrapie and mastitis, Nat. Med. (2005) 11:1137-1138.

[52] Lim M.M., Young L.J. Neuropeptidergic regulation of affiliative behaviour and social bonding in animals, Horm. Behav. (2006) 50:506-517.

[53] Lipsky S., Brandt H., Luhken G., Erhardt G., Analysis of prion protein genotypes in relation to reproduction in local and cosmopolitan German sheep breeds, Anim. Reprod. Sci. (2006) 103:69-77.

[54] Liu J., Litman D., Rosenberg M.J., Yu S., Biesecker L.G., Weinstein L.S., A GNAS1 imprinting defect in pseudo-hypoparathyroidism type IB, J. Clin. Invest. (2000) 106:1167-1174.

[55] Liu X., Huang W., Li C., Li P., Yuan J., Li X., et al., Interaction between c-Abl and Arg tyrosine kinases and proteasome subunit PSMA7 regulates proteasome degradation, Mol. Cell (2006) 22:317-327.

[56] Man W.Y.N., Brotherstone S., Merrel B.G., Murray W.A., Villanueva B., Associations of $\operatorname{Pr} P$ genotypes with live weight and slaughter traits in an experimental flock of Swaeldale sheep in Great Britain, Anim. Sci. (2006) 82:607-614.

[57] Manson J., West J.D., Thomson V., McBride P., Kaufman M.H., Hope J., The prion protein gene: a role in mouse embryogenesis, Development (1992) 115:117-122.

[58] Mantovani G., Ballare E., Giammona E., BeckPeccoz P., Spada A., The Gs-alpha gene: predominant maternal origin of transcription in human thyroid gland and gonads, J. Clin. Endocrinol. Metab. (2002) $87: 4736-4740$.

[59] Mor-Vaknin N., Punturieri A., Sitwala K., Markovitz D.M., Vimentin is secreted by activated macrophages, Nat. Cell Biol. (2003) 5:59-63.

[60] Moudjou M., Frobert Y., Grassi J., La Bonnardiere C., Cellular prion protein status in sheep: tissue-specific biochemical signatures, J. Gen. Virol. (2001) 82:2017-2024.

[61] Moum T., Olsaker I., Hopp P., Moldal T., Valheim M., Moum T., et al., Polymorphisms at codons 141 and 154 in the ovine prion protein gene are associated with scrapie Nor98 cases, J. Gen. Virol. (2005) 86:231-235.

[62] Naylor M.J., Li N., Cheung J., Lowe E.T., Lambert E., Marlow R., et al., Ablation of betal integrin in mammary epithelium reveals a key role for integrin in glandular morphogenesis and differentiation, J. Cell. Biol. (2005) 171:717-728.

[63] O’Doherty E., Aherne M., Ennis S., Weavers E., Roche J.F., Sweeney T., Prion protein gene polymorphisms in pedigree sheep in Ireland, Res. Vet. Sci. (2001) 70:51-56.

[64] O'Doherty E., Healy A., Aherne M., Hanrahan J.P., Weavers E., Doherty M., et al., Prion protein $(\operatorname{PrP})$ gene polymorphisms associated with natural scrapie cases and their flock-mates in Ireland, Res. Vet. Sci. (2002) 73:243-250.

[65] Pammer J., Weinger W., Tschachier E., Human keratinocytes express cellular prion-related protein in vitro and during inflammatory skin diseases, Am. J. Pathol. (1998) 153:1353-1358.

[66] Pammer J., Suchy A., Rendl M., Tschachler E., Cellular prion protein expressed by bovine squamous epithelia of skin and upper gastrointestinal tract, Lancet (1999) 354:1702-1703.

[67] Parry H.B., Scrapie disease in sheep, Oppentheimer D.R. (Ed.), Academic Press, New York, USA, 1983.

[68] Phaneuf S., Europe-Finner G.N., Carrasco M.P., Hamilton C.H., Lopez Bernal A., Oxytocin signalling in human myometrium, Adv. Exp. Med. Biol. (1995) 395:453-467.

[69] Ponz R., Tejedor M.T., Monteagudo L.V., Arruga M.V., Scrapie resistance alleles are not associated with lower prolificity in Rasa Aragonesa sheep., Res. Vet. Sci. (2006) 81:37-39.

[70] Porter V., Mason's world dictionary of livestock breeds, types and varieties, 5th ed., CABI Publishing, Oxon, UK, 2002, 380 p.

[71] Purvis I.W., Hilliard M., Biology and genetics of reproduction, in: Piper L.R., Ruvinsky A. (Eds.), The genetics of sheep, CAB International, Oxon, UK, 1997.

[72] Salaris S., Casu S., Carta A., Investigating the relationship between the prion protein locus and udder morphology traits and milk yield in Sardinian sheep, J. Anim. Sci. (2007) 85:2840-2845.

[73] Saunders G.C., Cawthraw S., Mountjoy S.J., Hope J., Windl O., PrP genotypes of atypical scrapie cases in Great Britain, J. Gen. Virol. (2006) 87:31413149.

[74] Sawalha R.M., Brotherstone S., Man W.Y.N., Conington J., Bunger L., Simm G., Villanueva B., 
Associations of polymorphisms of the ovine prion protein gene with growth, carcass and computerized tomography traits in Scottish Blackface lambs, J. Anim. Sci. (2007) 85:632-640.

[75] Suzuki K., Okuno T., Yamamoto M., Pasterkamp R.J., Takegahara N., Takamatsu H., et al., Semaphorin 7A initiates T-cell-mediated inflammatory responses through alpha-1-beta-1 integrin, Nature (2007) 446:680-684.

[76] Sweeney T., Hanrahan J.P., O’Doherty E., Is there a relationship between prion protein genotype and ovulation rate and litter size in sheep? Anim. Reprod. Sci. (2007) 101:153-157.

[77] Thorgeirsdottir S., Sigurdarson S., Thorisson H.M., Georgsson G., Palsdottir A., PrP gene polymorphisms and natural scrapie in Icelandic sheep, J. Gen. Virol. (1999) 80:2527-2534.

[78] Thumdee P., Ponsuksili S., Murani E., Nganvongpanit K., Gehrig B., Tesfaye D., et al., Expression of the prion protein gene (PRNP) and cellular prion protein (PrPC) in cattle and sheep fetuses and maternal tissues during pregnancy, Gene Expr. (2007) 13:283-297.

[79] Tongue S.C., Pfeiffer D.U., Warner R., Elliot H., Del Riovilas V., Estimation of the relative risk of developing clinical scrapie: the role of prion protein (PrP) genotype and selection bias, Vet. Rec. (2006) 158:43-50.

[80] Tongue S.C., Pfeiffer D.U., Heasman L., Simmons H., Ryder S.J., $\operatorname{Pr} P$ genotype and lamb birth weight in a scrapie-free environment: is there an association? Livest. Sci. (2006) 105:120-128.

[81] Townsend S.J., Warner R., Dawson M., PrP genotypes of rare breeds of sheep in Great Britain, Vet. Rec. (2005) 156:131-134.

[82] Vaccari G., D’Agostino C., Nonno R., Rosone F., Conte M., Di Bari M.A., et al., Prion protein alleles showing a protective effect on the susceptibility of sheep to scrapie and bovine spongiform encephalopathy, J. Virol. (2007) 81:7306-7309.

[83] Vitezica Z.G., Moreno C.R., Bouix, J., Barillet F., Perret G., Elsen J.M., A study on associations between $\operatorname{PrP}$ genotypes and meat traits in French sheep breeds, Anim. Sci. (2005) 81:325-330.

[84] Vitezica Z.G., Moreno C.R., Bodin L., Francois D., Barillet F., Brunel J.C., et al., No associations between $\operatorname{Pr} P$ genotypes and reproduction traits in INRA 401 sheep, J. Anim. Sci. (2006) 84:1317-1322.

[85] Vitezica Z.G., Moreno C.R., Lantier F., Lantier I., Schibler L., Roig A., et al., Quantitative trait loci linked to PRNP gene controlling health and production traits in INRA 401 sheep, Genet. Sel. Evol. (2007) 39:421-430.

[86] Yen T.T., Gill A.M., Frigeri L.G., Barsh G.S., Wolff G.L., Obesity, diabetes, and neoplasia in yellow $\mathrm{A}(\mathrm{vy}) /$ mice: ectopic expression of the agouti gene, FASEB J. (1994) 8:479-488. 